\title{
PERAN GURU DALAM ADMINISTRASI KURIKULUM
}

\author{
Noraidarayanti \\ Email: 2010128220011@mhs.ulm.ac.id \\ Program Studi Pendidikan IPS Fakultas Keguruan dan Ilmu Pendidikan \\ Universitas Lambung Mangkurat \\ Banjarmasin
}

\begin{abstract}
Abstrak
Artikel ini membahas mengenai administrasi kurikulum yang dimana pengertian dari administrasi kurikulum sendiri adalah seluruh proses kegiatan yang direncanakan serta diusahakan secara sengaja dan bersungguh-sungguh serta pembinaan secara berkelanjutan terhadap situasi kegiatan pembelajaran secara efektif dan efisien yang bertujuan guna membantu tercapainya tujuan pendidikan yang telah ditetapkan. Pada jenjang sekolah apapun, tugas utama seorang kepala sekolah adalah menjamin adanya program pengajaran yang baik dan tepat bagi peserta didik. Tujuan dari penulisan artikel ini adalah memberikan pengertian mengenai administrasi kurikulum.
\end{abstract}

Kata kunci : Administrasi, Kurikulum, Sekolah

\section{PENDAHULUAN}

Administrasi diperlukan untuk kelangsungan proses kegiatan pembelajaran dalam ranah pendidikan. Seseorang yang memegang administrasi merupakan seorang yang terlatih di bidangnya atau orang yang telah mendapatkan ilmu serta pelatihan. Administrasi tidak hanya dilakukan dalam waktu tertentu saja, namun dilakukan setiap hari secara berkelanjutan. Administrasi merupakan upaya yang bertujuan untuk menjadikan kegiatan kerja sama antara seorang guru, tenaga pendidik, serta peserta didik agar terciptanya proses pembelajaran yang lebih efektif.

Kurikulum merupakan suatu sistem program pembelajaran untuk mencapai tujuan institusional pada lembaga pendidikan, sehingga kurikulum memegang peranan yang penting dalam mewujudkan sebuah sekolah yang bermutu. Salah satu aspek yang 
mempengaruhi keberhasilan kurikulum adalah pemberdayaan bidang manajemen ataupun pengelolaan kurikulum pada tingkat satuan pendidikan atau sekolah perlu dikoordinasi oleh pihak pimpinan lembaga dan pembantu pimpinan yang dikembangkan secara integral dalam konteks manajemen berbasis sekolah dan kurikulum tingkat satuan pendidikan serta disesuaikan dengan visi dan misi lembaga pendidikan yang bersangkutan (Lilis Mustofa, 2018).

\section{METODE PENELITIAN}

Metode penelitian dari penulisan artikel ini adalah dengan menggunakan metode literatur yang dimana mengumpulkan dari sumber-sumber terpecaya seperti, jurnal, artikel, tesis, skripsi, buku, dan sumber lainnya. Kemudian dituliskan dalam artikel ini yang bertujuan untuk memberikan pemahaman mengenai administrasi kurikulum secara singkat, padat, dan jelas.

\section{PEMBAHASAN}

Administrasi adalah subsistem dari organisasi yang unsur-unsurnya terdiri dari unsur organisasi yaitu tujuan, orang, sumber, dan waktu (Daryanto, 2011) menurut pendapat Suryosubroto, 2004 kurikulum adalah segala pengalaman pendidikan yang diberikan oleh sekolah kepada seluruh peserta didiknya, baik itu dilakukan di dalam sekolah maupun luar sekolah. Pengalaman peserta didik disekolah dapat diperoleh melalui berbagai kegiatan pendidikan antara lain: mengikuti pelajaran dikelas, praktik keterampilan, latihan-latihan olah raga dan kesenian serta kegiatan wisata ataupun praktik di dalam laboratorium sekolah.

Kata kurikulum berasal dari Bahasa Latin "currere" yang memiliki arti sebagai lapangan perlombaan lari. Sedangkan definisi dari kurikulum pendidikan adalah seluruh proses kegiatan yang direncanakan dan diusahakan secara sungguh-sungguh dan pembinaan secara berkelanjutan terhadap situasi belajar mengajar di sekolah (Seiski Afrita Riska, 2020). Menurut Undang- Undang No. 20 Tahun 2003 Pasal 1 Ayat 19 Kurikulum merupakan seperangkat perencanaan dan pengaturan mengenai tujuan, isi, 
serta bahan pengajaran yang digunakan sebagai pedoman pembelajaran dengan tujuan untuk mencapai pendidikan.

Sebelum membentuk kurikulum maka perlu melakukan perencanaan misalnya seperti bagaimana bentuk dari kurikulum yang akan dibuat. Perencanaan kurikulum ini sebaiknya dilakukan oleh seorang ahlinya dikarenakan merancang dari suatu kurikulum tersebut sebaiknya sesuai dengan yang kemudian diharapkan. Dalam perencanaan kurikulum juga membahas situasi pembelajaran serta peserta didik yang berada diruang lingkup sekolah tersebut.

Dalam bidang administrasi kurikulum, adapun beberapa peran yang menjadi tugas seorang guru. Tugas-tugas tersebut masuk pada dua bagian, yaitu sentralisasi dan desentralisasi. Tugas sentralisasi di ruang lingkup sekolah meliputi perumusan atas kompetensi ataupun tujuan khusus pembelajaran, termasuk di dalamnya berkaitan dengan penetapan bidang studi serta peraturan sekolah. Selain itu seorang guru juga melakukan perencanaan kegiatan belajar mengajar serta program untuk mencapai kompetensi yang telah ditetapkan. Selain itu seorang guru juga berperan dalam hal evaluasi berdasarkan kegiatan belajar mengajar yang akan dijalankan. Adapun tugas seorang guru dalam hal desentralisasi yaitu pengembangan terhadap komponen kurikulum dengan meliputi perencanaan dan pengembangan kurikulum, implementasu program-program yang terdapat di kurikulum serta evaluasi secara rubin apabila ditemukan kurang maksimalnya peran kurikulum yang diterapkan. Secara operasional kegiatan administrasi kurikulum dapat di identifikasikan menjadi tiga kegiatan pokok yakni: Kegiatan yang berhubungan dengan tugas guru ataupun pendidik, kegiatan yang berhubungan dengan peserta didik, dan kegiatan yang berhubungan dengan seluruh aktivitas akademika atau warga sekolah (Gunawan, 1996: 80).

Fungsi kurikulum bagi peserta didik adalah sebagai sarana dalam mengukur kemampuan diri dan konsumsi pendidikan. Berkaitan dengan pencapaian target yang membuat peserta didik mudah memahami berbagai materi serta mampu melaksanakan proses pembelajaran setiap harinya dengan mudah, selain itu dengan fungsi kurikulum ini akan mempermudah peserta didik dalam memetakan jadwal. Melalui jadwal yang tersusun rapi dan terencana baik, peserta didik bisa disiplin membagi pekerjaan. Fungsi kurikulum untuk peserta didik lainnya, adalah mampu memetakan apa yang harus 
peserta didik kerjakan dari waktu ke lain waktu sesuai dengan evaluasi yang dikerjakan oleh guru.

Adapun fungsi kurikulum bagi tenaga pendidik ataupun guru, kurikulum sangat berguna dalam penerapan cara mengajarnya menjadikan guru merasa sangat terbantu, karena mampu mengajar dengan mengikat struktur yang telah dibuat. Baik dalam penyampaian materi maupun evaluasi yang hendak dilakukan terhadap peserta didik. Fungsi kurikulum juga dapat diartikan sebagai pedoman kerja bagi pihak guru ataupun tenaga pendidik. Keberadaan kurikulum bisa dijadikan bahan evaluasi terhadap perkembangan peserta didik dalam menyerap ilmu dan pengalaman praktik yang diberikan.

\section{SIMPULAN}

Administrasi adalah subsistem dari organisasi yang unsur-unsurnya terdiri dari unsur organisasi yaitu tujuan, orang, sumber, dan waktu. kurikulum adalah segala pengalaman pendidikan yang diberikan oleh sekolah kepada seluruh peserta didiknya, baik itu dilakukan di dalam sekolah maupun luar sekolah. Menurut Undang- Undang No. 20 Tahun 2003 Pasal 1 Ayat 19 Kurikulum merupakan seperangkat perencanaan dan pengaturan mengenai tujuan, isi, serta bahan pengajaran yang digunakan sebagai pedoman pembelajaran dengan tujuan untuk mencapai pendidikan. Fungsi kurikulum bagi peserta didik adalah sebagai sarana dalam mengukur kemampuan diri dan konsumsi pendidikan. Adapun fungsi kurikulum bagi tenaga pendidik ataupun guru, kurikulum sangat berguna dalam penerapan cara mengajarnya menjadikan guru merasa sangat terbantu, karena mampu mengajar dengan mengikat struktur yang telah dibuat. Kurikulum merupakan suatu sistem program pembelajaran untuk mencapai tujuan institusional pada lembaga pendidikan, sehingga kurikulum memegang peranan yang penting dalam mewujudkan sebuah sekolah yang bermutu. 
Manajemen Administrasi Sekolah

\section{DAFTAR PUSTAKA}

Afriansyah, H. (2019). 2. ADMINISTRASI KURIKULUM.

Anjelya, F. Administrasi kurikulum sekolah.

Efendi, A., \& Afriansyah, H. (2019). Administrasi Kurikulum.

Hidayah, L. (2020). PELAKSANAAN ADMINISTRASI KURIKULUM DALAM PROSES PEMBELAJARAN DI MADRASAH TSANAWIYAH AL-KAUTSAR SUMBERSARI SRONO BANYUWANGI TAHUN PELAJARAN 2019/2020 (Doctoral dissertation, INSTITUT AGAMA ISLAM NEGERI (IAIN) JEMBER).

Jeflin, H., \& Afriansyah, H. (2020). Pengertian Kurikulum, Proses Administrasi Kurikulum Dan Peran Guru Dalam Administrasi Kurikulum.

Masluroh, H. (2017). Sistem Online Administrasi Kurikulum Sebagai Solusi Perbaikan Layanan Administrasi Di Sma Nahdlatul Ulama 1 Gresik. DIDAKTIKA: Jurnal Pemikiran Pendidikan, 19(2), 1-10.

Rahmadita, S. (2019). Administrasi kurikulum.

Riska, S. A., \& Afriansyah, H. (2019). Administrasi Kurikulum.

Tjeriawan, C. A., \& Afriansyah, H. (2019). Administrasi Kurikulum. 